\title{
LA INVESTIGACIÓN INDEPENDIENTE: ESPECIE EN PELIGRO DE EXTINCIÓN
}

\section{INDEPENDENT RESEARCH: ENDANGERED SPECIES}

\section{AUTORES}

Luis A. Rubio: Científico Titular Estación Experimental del Zaidín (CSIC) Depto. de Nutrición

1rubio@,eez.csic.es

\section{CURRÍCULUM VITAE}

Científico Titular Estación Experimental del Zaidín (Consejo Superior de Investigaciones Científicas -CSIC-) (España). Miembro del Departamento de Nutrición.

\section{RESUMEN}

Teníamos previsto, en este número, incluir un largo e interesantísimo artículo de divulgación sobre fractales, escrito por un alumno de la UAH, habitual colaborador de nuestra revista. Sin embargo, dada su longitud y la inquietante noticia que nos ha llegado a través de nuestros compañeros del C.S.I.C., hemos creído más conveniente no engrosar demasiado el número diez y dar salida a este comunicado y sus informaciones adicionales sobre cultivos transgénicos.

\section{PALABRAS CLAVE}

Investigación independiente - Especies - Peligro de extinción 


\begin{abstract}
We had planned on this issue, including a long and interesting article on fractals disclosure, written by a student at $\mathrm{UAH}$, a regular contributor to our magazine. However, given its length and the disturbing news that has come through our partners in the CSIC, we thought it best not too swell the number ten, and output to this press release and additional information on GM crops.
\end{abstract}

\title{
KEY WORDS
}

Independent Research - Species - Endangered species

Teníamos previsto, en este número, incluir un largo e interesantísimo artículo de divulgación sobre fractales, escrito por un alumno de la UAH, habitual colaborador de nuestra revista. Sin embargo, dada su longitud y la inquietante noticia que nos ha llegado a través de nuestros compañeros del C.S.I.C., hemos creído más conveniente no engrosar demasiado el número diez y dar salida a este comunicado y sus informaciones adicionales sobre cultivos transgénicos.

La noticia se refiere a la reacción de las autoridades británicas ante una declaraciones de un especialista que, al parecer contrariaban directamente las nuevas tendencias en alimentación. 
El caso es gravísimo, por cuanto representa un ejemplo claro de lo que hemos venido denunciando reiteradamente desde Vivat Academia. La privatización de la investigación a que nos quieren llevar las autoridades académicas actuales, y nuestro equipo de gobierno es ferozmente pionero de este sistema "innovador", lleva inmediatamente a matar, por la vía rápida, toda independencia del quehacer científico: "Sólo investigaremos lo que los poderes económicos quieran y, lo que es peor, sólo se conocerán los resultados que esos mismos poderes estén dispuestos a dar a conocer".

\section{COMUNICADO DEL DR. RUBIO}

Estimados compañeros/as,

Debido a su difusión en los medios, muchos de vosotros estaréis más o menos al corriente de la discusión planteada en relación con los llamados alimentos transgénicos. Durante los últimos 8-10 meses, esta discusión se ha extendido a más amplios sectores sociales y se ha transformado en polémica, en gran medida como consecuencia de lo ocurrido en el Reino Unido a partir de las declaraciones para una cadena de televisión realizadas por el Dr A. Pusztai, investigador del Rowett Research Institute (Aberdeen, Escocia). La situación originada en aquel país por parte de las autoridades, especialmente por la forma en que éstas trataron la cuestión, dió lugar a que una serie de científicos, especialistas en diferentes áreas relacionadas con las investigaciones del Dr Pusztai, hiciesen público un Memorandum, (que podéis leer pulsando aquí).

Yo mismo soy uno de los firmantes de ese Memorandum debido a que mi área de trabajo es la Nutrición (aunque no específicamente con alimentos transgénicos), y he desarrollado gran parte de mi investigación en colaboración con el Dr Pusztai. Por tanto, dado que conozco de primera mano su investigación, sus planteamientos y su 
forma de trabajar, accedí a estudiar sus resultados y a darle mi opinión desde un punto de vista estrictamente científico, como hicieron el resto de los firmantes. Sobre la base de las diferentes revisiones realizadas se redactó el Memorandum publicado el 12/2/99, y que os remito adjunto. En este momento, los resultados obtenidos por el Dr Pusztai están en trámite de publicación en revistas científicas adecuadas.

Junto con el Memorandum os adjunto dos documentos que pueden servir para hacerse una idea más clara sobre el estado de la cuestión. Ambos son artículos publicados en medios científicos oficiales:

1.- Llamamiento difundido en Plant Breeding News 96, Boletín Electrónico de la FAO, 27 de abril de 1999.

2.- "UK scientists meeting with minister". En este segundo documento se facilita una página web

--http://www.bma.org.uk/public/science/genmod.htm--

que contiene el artículo "The Impact of Genetic Modification on Agriculture, Food and Health - An Interim Statement" publicado por la British Medical Association (Board of Science and Education, Mayo 1999). (Los dos documentos pueden ser consultados pulsando con el botón izquierdo del ratón en el área que señala la vinculación).

La razón de enviaros este mensaje, aparte de indicar dónde puede encontrar alguna información quien tenga interés en ello, es solicitar la adhesión al llamamiento expresado en el documento "Transg1" del Plant Breeding News de aquellos que estén de acuerdo con él. Su finalidad es plantear a las autoridades la necesidad de establecer una moratoria básicamente de tipo comercial en relación con estos productos por razones científicas, como se expresa al principio del documento mencionado. Os ruego por tanto que quienes estéis de acuerdo con el llamamiento solicitando una moratoria me lo hagáis saber para poder hacerlo valer en los medios 
adecuados. Podéis utilizar para ello tanto el correo electrónico como el normal o el fax. Estamos por lo demás abiertos a cualquier tipo de comentario, crítica o desacuerdo, por lo que os agradecería igualmente que quienes no estéis de acuerdo con este planteamiento me hagáis llegar vuestras razones si os parece conveniente.

Recibid un saludo,

Luis A. Rubio

Científico Titular Estación Experimental del Zaidín (CSIC)

Depto. de Nutrición

Cno. del Jueves, s/n 18100 Armilla (GRANADA)

Tel: +34-58-572757

Fax: +34-58-572753

lrubio@eez.csic.es

Acabamos de recibir del Dr. Rubio unos artículos de la Revista Lancet que hacen referencia directa a los posibles problemas de los alimentos transgénicos. Por si alguno de nuestros lectores tiene interés en consultarlos, los añadimos a continuación:

\section{Adequacy of methods for testing the safety of genetically modified foods}

Lancet. Volume 354, Number 918716 October 1999

An issue that has been prominent in the current debate on the health risks of genetically modified (GM) foods is whether there are adequate methods of testing for the safety of these foods. One view is that the safety assessments of these foods are not as rigorous as those for new chemicals or drugs. Today's Lancet carries two 
Research Letters reporting work on the potential risks to human health of the lectin Galanthus nivalis agglutinin (GNA), a compound that may be useful in protecting food plants from attacks by insects. These letters raise issues about the design of studies on safety.

Stanley Ewen and Arpad Pusztai report that, when fed to rats, GM potatoes containing the GNA lectin have proliferative and antiproliferative effects on the gut. They suggest that several of these effects are due to alterations in the composition of the transgenic potatoes, rather than to the newly expressed gene product. However, data on the composition of the different diets are not reported in the letter. Pusztai has released some of these details on the internet (http://www.rri.sari.ac.uk/gmo/ajp.htm ). These details indicate that the content of starch, glucose polymers, lectin, and trypsin and chymotrypsin inhibitors in GM potatoes differed from that of the parental line. Unfortunately, these differences have not been examined further by analysis of an extended range of lines, for evidence on whether these $\mathrm{d}$ ! ifferences are attributable to the genetic modification or to natural variations. Another shortcoming of the study is that the diets were protein deficient; they contained only $6 \%$ protein by weight. There is convincing evidence that shortterm protein stress and starvation impair the growth rate, development, hepatic metabolism, and immune function of rats.1,2

Ewen and Pusztai say that the significant differences between diet groups in variables such as mucosal thickness or crypt length are evidence of the biological effects of the GM foods. Such a claim is easy to make but difficult to prove, because no consistent patterns of changes were observed in the study. Ingestion of potatoes may be associated with several adaptive changes in the gut because of the low digestibility of raw or partly refined potato starch. In rats caecal hypertrophy is a common response to short-term feeding of various poorly digestible carbohydrates, such as raw potato starch.3,4 A physiological response of this nature is probably of 
little toxicological significance. Dose-response studies would have helped in the assessment of consistency of response.

The experiments done by Ewen and Pusztai were incomplete, included too few animals per diet group,5 and lacked controls such as a standard rodent diet containing about 15\% protein (lactalbumin) as a balanced source of aminoacids6 and a test diet with potatoes containing an "empty" vector. Therefore the results are difficult to interpret and do not allow the conclusion that the genetic modification of potatoes accounts for adverse effects in animals. Similar criticisms of this work have been made by the Royal Society (http://www.royalsoc.ac.uk/ st_pol54.htm ).

In the second Research Letter, Brian Fenton and colleagues provide data that indicate strong binding of GNA to human white blood cells in vitro. Binding per se of a lectin does not automatically imply cell activation. Nevertheless, such findings emphasise the need for further studies. Attention should not be confined to the gastro-intestinal tract, but should also be paid to the bioavailability of these compounds and their potential toxic effects once they have entered the systemic circulation. Such investigations will be of paramount importance for future generations of GM foods (see below). An extensive toxicological study of this type has been done with a GM tomato containing an insecticidal protein derived from Bacillus thuringiensis.7

What about the adequacy of existing test methods and strategies for the assessment of the safety of GM foods? Internationally agreed strategies for the evaluation of the safety of transgenic food crops with improved agronomic properties have been drawn up. The assessments have consisted of the characterisation of the new gene products, identification of alterations in concentrations of nutrients and known toxicants, and evaluation of the potential allergenicity of the gene product and of the implications of gene transfer between plants and the gut microflora of animals or human beings. 8 The first approach to safety assessment is a comparative one--ie, a 
new food is compared with a conventional product that long-term experience has shown to be safe (concept of substantial equivalence). 9 The data so far indicate that GM crops with agronomic advantages that have been introduced into the environment do not differ from the traditionally grown crops except $f$ ! or $t$ he inserted traits.

Safety testing will have to be adjusted for the "second generation" of food plants, which are modified to improve food-quality traits--eg, to raise the nutritional value of the proteins, to increase concentrations of oils low in saturated fats or of novel carbohydrates, or to fortify the foods with micronutrients or antioxidants. These must undergo extensive toxicological and nutritional assessment with a combination of in-vitro and in-vivo techniques as required for novel foods in general.10

Particular attention must be given to the detection and characterisation of unintended effects of genetic modifi-cation. Inferences about such effects can no longer be based solely on chemical analysis of single macronutrients and micronutrients and known crop-specific antinutrients or toxins. New methods have been developed to screen for potential alterations in the metabolism of the modified organism by analysis of gene expression (monitored by microarray technology, mRNA fingerprinting), by overall protein analysis (proteomics), and by secondary metabolite profiling.11,12 Depending on the outcome of these studies, further toxicological and nutritional studies may be needed.

In summary, methods to assess the safety of GM foods that are already on the market are adequate, but the future generation of such foods will need a wider range of tests covering both toxicological and nutritional endpoints. The studies must be designed carefully because of the complexity of foods.13 This complexity means that the adoption, as recently proposed,14 of an approach used for pesticides and food additives--the establishment of an "acceptable daily intake"--is inappropriate. Results 
of studies into GM foods should be interpreted with caution and presented to the scientific community in sufficient detail.

*Harry A Kuiper, Hub P J M Noteborn, Ad A C M Peijnenburg

RIKILT (National Institute for Quality Control of Agricultural Products), Wageningen University and Research Centre, Wageningen, NL-6700 AE, Netherlands

1 Konno A, Utsuyama M, Kurashima C, Kasai M, Kimura S, Hirokawa K. Effects of a protein-free diet or food restriction on the immune system of Wistar and Buffalo rats at different ages. Mech Ageing Dev 1993; 72: 183-97.

2 Le Moullac B, Gouache P, Bleiberg DF. Regulation of hepatic transthyretin messenger RNA levels during moderate protein and food restriction in rats. J Nutr 1992; 122: 864-70.

3 Walker R. Some observations on the phenomenon of caecal enlargement in the rat. In: Gali CL, Paoletti R, Vettorazzi G, eds. Chemical toxicology of food, vol 3. Amsterdam: Elsevier/North-Holland Biomedical Press, 1978: 339-48.

4 Lopez HW, Coudray C, Bellanger J, Younes H, Demigne C, Remesy C. Intestinal fermentation lessens the inhibitory effects of phytic acid on mineral utilization in rats. J Nutr 1998; 128: 1192-98.

5 OECD guideline for testing of chemicals 407. Repeated dose oral toxicity--rodent 28-day or 14-day study, adopted May 12, 1981. Paris, OECD. 
6 Committee on Animal Nutrition, Board on Agriculture, National Research Council.Nutrient requirements of laboratory animals, 4th edn. Washington: National Academy Press, 1995: 23.

7 Noteborn HPJM, Bienenmann-Ploum ME, van den Berg JHJ, et al. Safety assessment of the Bacillus thuringiensis insecticidal crystal protein CryIA(b) expressed in transgenic tomatoes. In: Engel K-H, Takeoka GR, Teranishi R, eds. Genetically modified foods: safety issues. ACS Symposium Series 605, Washington DC, 1995: 134-47, 1995.

8 FAO/WHO. Joint FAO/WHO Expert Consultation on Biotechnology and Food Safety, Rome, 1996.

9 OECD. Safety evaluation of foods derived by modern biotechnology: concepts and principles. Paris: OECD, 1993.

10 Regulation (EC) no 258197 of the European Parliament and the council. Official J European Communities 1997 no L43, 1-7.

11 Van Hal NLW, Vorst O, Van Houwelingen AMML et al. The application of DNA micro-arrays in gene expression analysis. J Biotechnol (in press).

12 Noteborn HPJM, Lommen A, Van der Jagt RC, Weseman JM, Kuiper HA. Chemical fingerprinting for the evaluation of unintended secondary metabolic changes in transgenic food crops. J Biotechnol (in press).

13 OECD. Food safety evaluation. Paris: OECD, 1996. 
14 Millstone E, Brunner E, Mayer S. Beyond "substantial equivalence". Nature 1999; 401: 525-26.

\section{Genetically modified foods: "absurd" concern or welcome dialogue?}

Lancet. Volume 354, Number 918716 October 1999

"The attempt of single-interest groups, supported by the tabloid press and now by others who should know better, to declare this whole [genetically modified] technology as dangerous and immoral is sad for the UK, but is also absurd".1 So wrote the president of the UK's Academy of Medical Sciences, Peter Lachmann, after The Lancet criticised Arpad Pusztai for announcing the results of his experiments with genetically modified (GM) potatoes on television. Lachmann had less to say about the journal's additional and equally important concern--namely, that those in government, the food industry, and science had badly miscalculated the level of public anxiety about this new biotechnology. 2

Richard Sykes, chairman of GlaxoWellcome, also marginalised the public's concern. In his presidential address to the British Association for the Advancement of Science on Sept 13, 1999, he noted that "It is now very possible that the outcomes of the present anti-GM food campaign will be detrimental to this country. It will lead to a failure to develop new UK companies based upon the technology developed here, loss of technical expertise as funding by major international companies is withdrawn, and disadvantage for British agriculture". This state of affairs was even more starkly summed up by Roger Gosden, the scientist acclaimed for the first successful ovary graft, who is emigrating from the UK to Canada in a blaze of publicity about the brain drain, who said that "With all the fuss over GM food and so on, it is difficult to be a scientist in Britain. One does not feel proud of being a scientist any longer".3 
The trigger for much of this despondency was the public debate that followed Pusztai's television revelations. The data on which this media furore was founded are published for independent assessment in this week's issue of The Lancet, 18 months after their first public release. The Research Letter by Stanley Ewen and Pusztai was received by the journal towards the end of 1998. Since then, it has been peer reviewed by six specialist advisers--a nutritionist, a human pathologist, a veterinary pathologist, an agricultural geneticist, a plant molecular biologist, and a statistician-who had several requests for clarification about the design of the study, the laboratory methods used, and the statistical tests applied. Some advised rejection; others encouraged us to go ahead and publish. The authors revised their letter three times to try to meet our reviewers' criticisms. The Royal Society's own i! nter nal review of the Pusztai data had led to the damning verdict that the study "is flawed in many aspects of design, execution, and analysis and that no conclusions should be drawn from it". So why publish the paper?

The answer lies partly in a February, 1999, statement from the UK's chief scientific adviser, Robert May.4 While criticising the researchers' "sweeping conclusions about the unpredictability and safety of GM foods", he pointed to the frustration that had dogged this entire debate: "Pusztai's work has never been submitted for peer review, much less published, and so the usual evaluation of confusing claim and counterclaim effectively cannot be made". This problem was underlined by our reviewers, one of whom, while arguing that the data were "flawed", also noted that, "I would like to see [this work] published in the public domain so that fellow scientists can judge for themselves ... if the paper is not published, it will be claimed there is a conspiracy to suppress information". Publication of Ewen and Pusztai's findings is not, as some newspapers have reported,5 a "vindication" of Pusztai's earlier claims. On the contrary, publication of a paper af! ter substantial review and revision provides a report that deserves further scientific attention. Such wider appraisal begins in this week's Lancet with the commentary by Harry Kuiper and colleagues . 
Once the sketchy details of these data had been revealed last year, several respected scientists and scientific institutions called for more careful government scrutiny of research into GM food. For example, the Royal Society's own statement on GM plants6 recommended that "any further increase in the number of antibiotic-resistant micro-organisms resulting from transfer of antibiotic-resistance markers from GM food should be avoided". The report supported labelling of foods containing GM material (a practice introduced last month in the UK) and threw its weight behind the idea of "an over-arching body or 'super-regulator'" to oversee all government advisory bodies on GM technology. The Royal Society also recommended further research into alternative markers to antibiotic-resistance genes, the impact of virusresistant and insect-tolerant plants on the ecosystem, and the unpredictable genetic effects resulting from gene insertion into a GM plant.

These concerns were echoed in Robert May's 1999 statement,4 which concluded that "there can be questions of health and safety associated with some GM foods, particularly if we introduce genes coding for production of toxins against certain kinds of pests". The Chief Medical Officer of England, Liam Donaldson, together with May, wrote that although "There is no current evidence to suggest that the GM technologies used to produce food are inherently harmful . . nothing can be absolutely certain in a field of rapid scientific and technological development.7 Donaldson and May urged the UK government to develop a comprehensive research strategy into GM food technology, including study of its potential effects on health.

These responses reflect an appropriately cautious approach towards the science of genetic modification. They reflect the real concern expressed by both "single- interest groups" and a wider public. These anxieties may seem odd, even irrational, given that GM foods were introduced in the USA without any sign of consumer anxiety. Why? Because Europe now lives in a post-BSE (bovine spongiform encephalopathy) 
age, one in which society has learned that the epidemic of BSE was brought on by unchecked industry-driven changes in farming practices and that the denials of risk by government and scientific authorities were worthless. That concern is now spreading beyond the UK. Recognition of this deeply ingrained public scepticism about food technology has led Monsanto to rethink its entire GM-food strategy.8,9

The comments by Lachmann, Sykes, and Gosden are therefore disappointing because they reflect a failure to understand the new, and apparently unwelcome, dialogue of accountability that needs to be forged between scientists and the public. Risks are not simply questions of abstract probabilities or theoretical reassurances. What matters is what people believe about these risks and why they hold those beliefs. Ewen and Pusztai's data are preliminary and non-generalisable, but at least they are now out in the open for debate, as are the results, also published in today's Lancet, of Brian Fenton and colleagues. Only by welcoming that debate will the standard of public conversation about science be raised. Berating critics rather than engaging them--and criticising reports of research, as the Royal Society did with the Pusztai data, before those data were reviewed and published in the proper way--will only intensify public scepticism about science and scientists.

Richard Horton

The Lancet, London WC1B 3SL, UK

1 Lachmann P. Health risks of genetically modified foods. Lancet 1999; 354: 69.

2 Editorial. Health risks of genetically modified foods. Lancet 1999; 353: 1811.

3 Dobson R. Medical stars pack their bags. Independent on Sunday Sept 26, 1999: 16. 
4 May R. Genetically modified foods: facts, worries, policies, and public confidence. London: Office of Science and Technology, 1999.

5 Lean G. Smeared GM expert vindicated. Independent on Sunday Oct 3, 1999: 1.

6 Royal Society. Genetically modified plants for food use. London: Royal Society, September, 1998.

7 Donaldson L, May R. Health implications of genetically modified foods. London: Department of Health, May, 1999.

8 Quinn S. Monsanto rethink welcomed. Guardian Sept 27, 1999: 4.

9 Finn G. Monsanto's U-turn on "terminator gene" seeds. Independent Oct 5, 1999: 1.

Effect of diets containing genetically modified potatoes expressing Galanthus nivalis lectin on rat small intestine

Lancet. Volume 354, Number 918716 October 1999

Stanley W B Ewen, Arpad Pusztai

Diets containing genetically modified (GM) potatoes expressing the lectin Galanthus nivalis agglutinin (GNA) had variable effects on different parts of the rat gastrointestinal tract. Some effects, such as the proliferation of the gastric mucosa, were mainly due to the expression of the GNA transgene. However, other parts of the construct or the genetic transformation (or both) could also have contributed to 
the overall biological effects of the GNA-GM potatoes, particularly on the small intestine and caecum.

See Commentaries by Horton and Kuipers et al

Genetically modified (GM) plant products are becoming increasingly common in the human food-chain, yet in contrast to the general acceptance of the need for the biological testing of novel foods and feedstuffs, few studies have been carried out on the possible effects of GM products on the mammalian ut mucosa. GM potatoes expressing a snowdrop lectin (Galanthus nivalis agglutinin [GNA]) under the CaMV35s promoter have been developed to increase insect and nematode resistance.1 GNA was selected for insertion into potatoes because the initial effect of this mannose-specific lectin on the rat small bowel has been shown to be minimal,2 and because its binding to mannose present on the epithelial surface of rat jejunal villi is demonstrable only after feeding for 10 days. We compared the histological indices of the gut of rats fed potato diets containing GM potatoes, non-GM potatoes, or non-GM potatoes supplemented with GNA, to find out whether GNA ! gene insertion had affected the nutritional and physiological impact of potatoes on the mammalian gut.

ELISA analysis confirmed that the expression level of GNA in raw GM potatoes was $254 \mu \mathrm{g} / \mathrm{g}$ dry matter; the concentration was decreased to $4.9 \mu \mathrm{g} / \mathrm{g}$ after boiling for 1 h. Six rats were randomly allocated to each group, and were fed diets containing either raw or boiled GNA-GM potatoes, parent potatoes (Desiree), or parent-line potatoes supplemented with $254 \mu \mathrm{g} / \mathrm{g}$ GNA for 10 days. All potato diets were isocaloric and contained an average of $6 \%$ protein. Histological samples of stomach, jejunum, ileum, caecum, and colon were taken 10 days after the start of feeding. The samples, each $2 \mathrm{~cm}$ in length, were opened along the antimesenteric border. The serosal surface was allowed to adhere to card for 3 min and was then fixed in $10 \%$ 
neutral buffered formalin for $18 \mathrm{~h}$ at $20^{\circ} \mathrm{C}$. Paraffin sections $(4 \mu \mathrm{m})$ were stained with haematoxylin and eosin, and mucosal thickness (stomach) or crypt length (jejunum, ileum, caecum, and colon) was measured by vid! eo-i mage analysis. Intraepithelial lymphocytes are equally distributed in all parts of the small intestine, and are known to increase when non-specific intestinal damage occurs. Thus, to assess potential damage, intraepithelial lymphocytes were counted in eight jejunal villi from each of the six rats fed diets containing GNA-GM potatoes or parent potatoes, both raw and boiled. No such measurements were made for the group fed parent potatoes spiked with GNA because dietary GNA or other lectins do not induce lymphocyte infiltration. GNA binding to the jejunum and ileum was measured by elution with $0 \cdot 1 \mathrm{~mol} / \mathrm{L}$ mannose, followed by ELISA.

The presence of GNA in the diets, irrespective of whether originating from GNA-GM potatoes or from parent-potato diets supplemented with GNA, was associated with significantly greater mucosal thickness of the stomach when compared with parentpotato diets (table 1). This effect was observed with both raw and boiled potatoes. Crypt length in the jejunum of rats fed on raw GNA-GM potato diets was significantly greater than in those given parent-line or parent-line plus GNA potato diets. However, the increase in jejunal crypt length was not seen in rats fed boiled GNA-GM potatoes (table 1). GNA had no significant effects on the ileum, but rats fed boiled potatoes had shorter ileal crypts than rats given respective raw potato diets. Rats fed boiled GNA-GM potatoes had significantly thinner caecal mucosae than rats given boiled parent potatoes, with or without GNA supplementation (table 1). Intraepithelial lymphocyte counts per 48 villi were $7 \cdot 6$ (SD 2.7 ) in rats fed on! boi led parent potatoes, compared with 10.3 (3.3) in rats fed boiled transgenic potatoes $(\mathrm{p}<0.01)$. With raw potato diets, the intraepithelial lymphocyte counts were again significantly different: $5.3(2 \cdot 0)$ and $9.3(2.6)$ in parent and GM potatoes, respectively $(\mathrm{p}<0.01)$. Peyer's patches appeared normal in all rats. GNA binding in the jejunum and ileum was about the same, irrespective of whether spiked GNA potatoes or GM 
potatoes were fed (table 2). Measurement of GNA binding by immunocytochemistry also showed a similar pattern. 2

Mean (SD) crypt length $(\mu \mathrm{m})$ and difference between treatments*

\section{Statistical analysis}

(p)

\section{Interactio}

n (p)

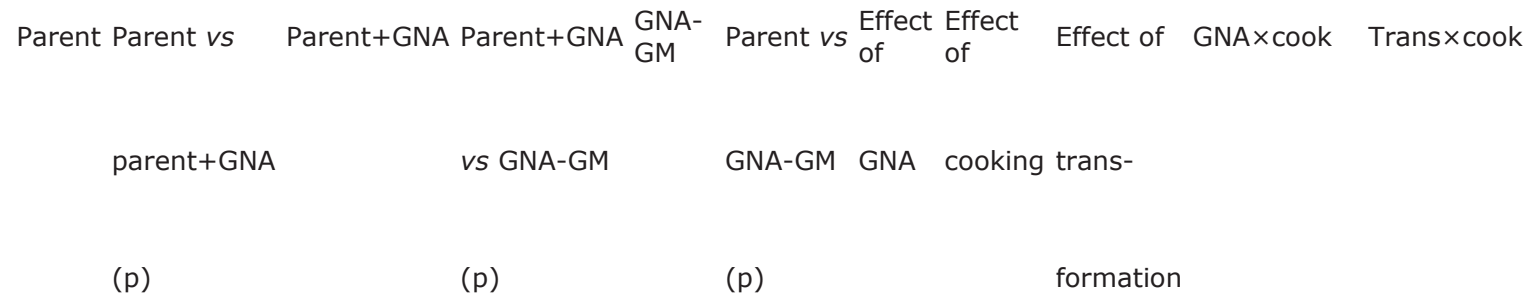

\section{Stomach}

\begin{tabular}{|c|c|c|c|c|c|c|c|c|c|c|}
\hline Boiled & $\begin{array}{l}294 \\
(46)\end{array}$ & $0 \cdot 29$ & $347(42)$ & 0.37 & $\begin{array}{l}339 \\
(36)\end{array}$ & 0.02 & 0.0010 .052 & 0.868 & 0.917 & $0 \cdot 543$ \\
\hline Raw & $\begin{array}{l}261 \\
(32)\end{array}$ & 0.03 & $312(32)$ & 0.98 & $\begin{array}{l}323 \\
(54)\end{array}$ & 0.07 & & & & \\
\hline $\mathrm{p}$ & 0.18 & & 0.94 & & 0.35 & & & & & \\
\hline
\end{tabular}

\section{Jejunum}

\begin{tabular}{|c|c|c|c|c|c|c|c|c|c|}
\hline Boiled & $\begin{array}{l}75 \\
(19)\end{array}$ & $0 \cdot 72$ & 78 (17) & 0.97 & $\begin{array}{l}78 \\
(12)\end{array}$ & $0 \cdot 71$ & 0.0290 .171 & 0.041 & 0.035 \\
\hline Raw & $57(8)$ & $0 \cdot 14$ & $64(11)$ & 0.01 & $\begin{array}{l}90 \\
(20)\end{array}$ & $<0.01$ & & & \\
\hline$p$ & 0.06 & & 0.09 & & 0.24 & & & & \\
\hline
\end{tabular}

\section{Ileum}

\begin{tabular}{|c|c|c|c|c|c|c|c|c|c|}
\hline Boilec & $59(8) 0 \cdot 20$ & $55(7)$ & $0 \cdot 12$ & $\begin{array}{l}63 \\
(13)\end{array}$ & 0.43 & 0.2210 .001 & $0 \cdot 106$ & 0.209 & 0.942 \\
\hline Raw & 71 (9) $0 \cdot 24$ & 79 (13) & 0.43 & $\begin{array}{l}87 \\
(25)\end{array}$ & 0.15 & & & & \\
\hline$n$ & 0.02 & $<0.01$ & & 0.06 & & & & & \\
\hline
\end{tabular}




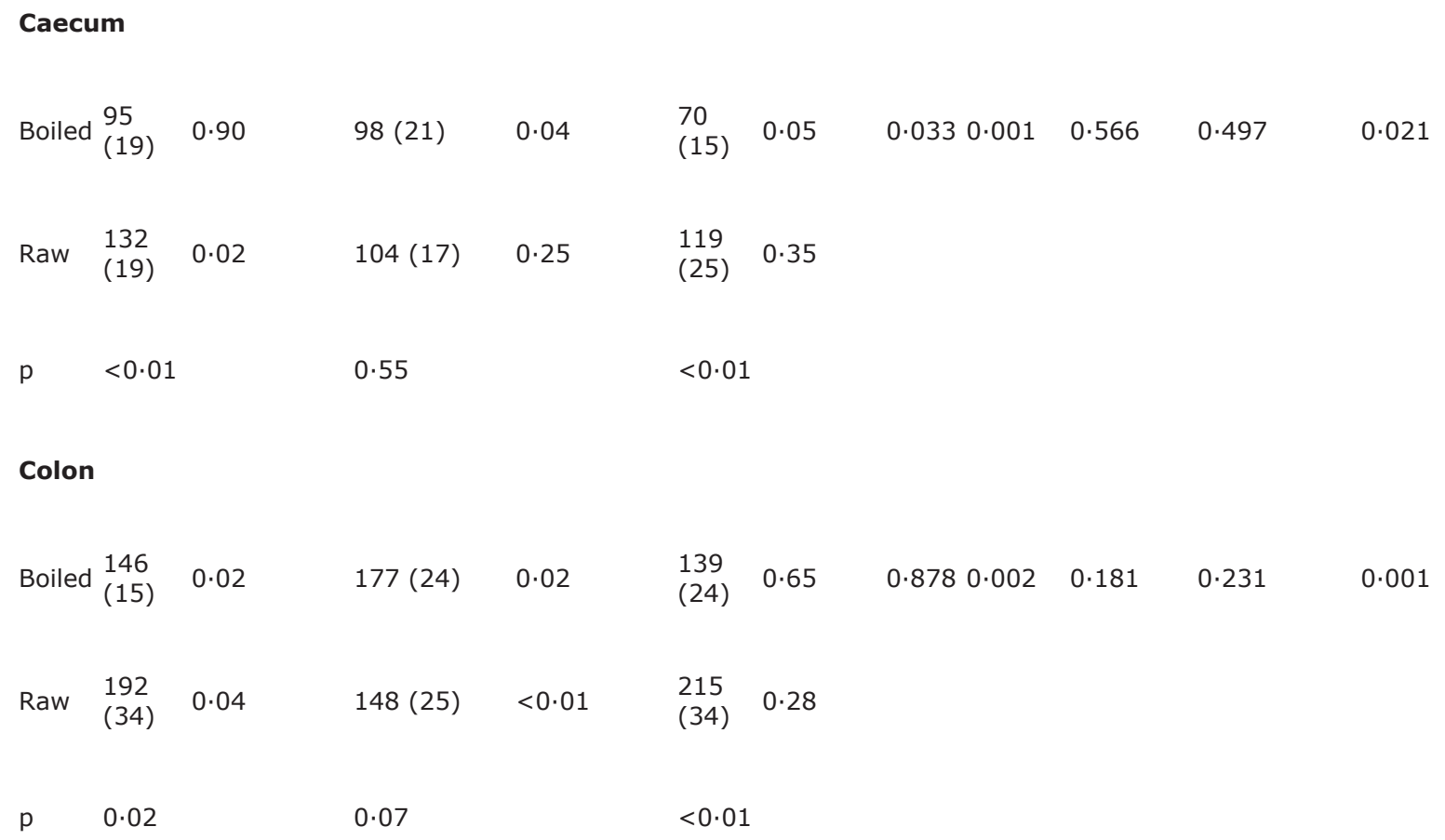

Data are the means of six animals calculated from five observations for each. GNA $\times$ cook=interaction between GNA and cooking; Trans $\times$ cook=interaction between transformation and cooking.

*By Student's t test.

By multivariate analysis with Tukey's test.

Table 1: Effect of raw and cooked parent, parent+GNA, and GNA+GM potatoes on histological indices of rat gut

We suggest that the promotion of jejunal growth was the result of the transformation of the potato with the GNA gene, since the jejunum of rats was shown to be stimulated only by GM potatoes but not by dietary GNA (table 1), in agreement with a previous study in which the dietary GNA concentration was 1000-fold higher than the one used in this study.2 Thus, we propose that the unexpected proliferative effect was caused by either the expression of other genes of the construct, or by some form of positioning effect in the potato genome caused by GNA gene insertion. Because 
caecal thickness was similar in rats given boiled parent potatoes in the presence or absence of spiked GNA, we suggest that the decrease in caecal mucosal thickness seen in rats fed boiled GM-potato diets was the consequence of the transfer of the GNA gene into the potato. Caecal mucosal thickness in rats given raw potato diets was significantly higher than in those given the corresponding boiled! potatoes. Thus, the main effect of boiling was to decrease mucosal thickness; this binding was fully in line with expectations. The raw parent-line potato diets supplemented with GNA were associated with a significantly thinner caecal mucosa than that of rats given parent-line potato diets. A similar trend was also observed in rats fed raw GNA-GM potatoes, but the difference did not reach significance (table 1).

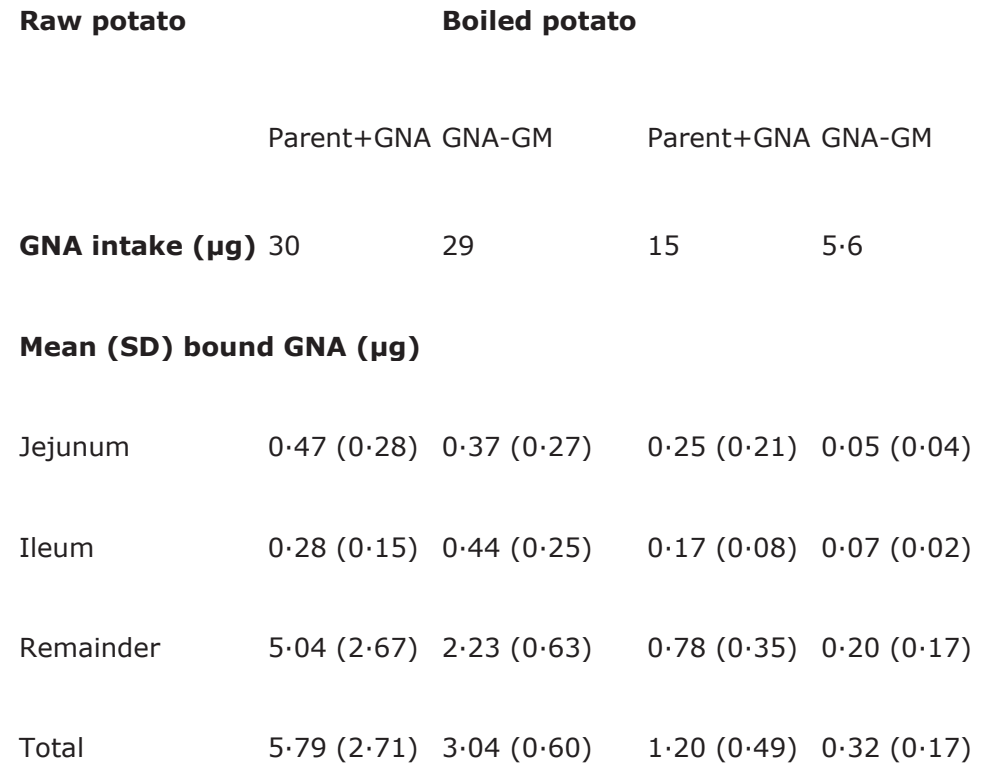

On the morning of day 10, rats were given $15 \mathrm{~g}$ allocated diet and were killed $2 \mathrm{~h}$ later. After dissection, oesophagus, pylorus, and ileocaecal junction were clipped, and small intestine was washed thoroughly with saline. Small intestine was cut into three segments: jejunum (first $20 \mathrm{~cm}$ ), ileum (last $20 \mathrm{~cm}$ ), and remainder. Tissues 
were homogenised with phosphate-buffered saline containing $0 \cdot 1 \mathrm{~mol} / \mathrm{L}$ mannose, and solutions were used for determination of GNA content by competitive ELISA. Table 2: GNA binding to the jejunum and ileum of rats given diets containing GNAGM potatoes or parent potato diets spiked with GNA

As expected, colonic crypt lengths were generally higher in rats given raw potato diets than in those given boiled potatoes, except for animals fed GNA-supplemented raw or boiled potato diets, between which there was no significant difference. Feeding rats on diets containing GM potatoes, irrespective of whether raw or boiled, had no significant effect on colonic crypt length compared with that in animals fed the corresponding parent-line potatoes (table 1). Rats fed on GNA-supplemented parent potatoes had significantly shorter colonic crypt lengths than those fed on parent potatoes of GNA-GM potatoes; the reason for this finding is not clear.

In conclusion, the stimulatory effect of GNA-GM potatoes on the stomach was mainly due to the expression of the GNA transgene in the potato. By contrast, the potent proliferative effect of raw GNA-GM potatoes on the jejunum, and the antiproliferative effect of boiled transgenic potatoes on the caecum can be attributed only partly to GNA gene expression. Other parts of the GM construct, or the transformation, could have contributed to the overall effects. Once bound, GNA is internalised by endocytosis;2 some other component of the construct in the GNA-GM potato or its expressed gene product might also be able to penetrate and affect the rat mucosal cells in a similar manner. The growth-promoting effect of raw GNA-GM potatoes in the jejunum, evident as crypt hyperplasia, is probably due to a direct stimulatory effect on crypt cells; the increase in $\mathrm{T}$ lymphocyte infiltration may be important in the elimination of damaged enterocytes.3 The possibility that! a $\mathrm{p}$ lant vector in common use in some GM plants can affect the mucosa of the gastrointestinal tract and exert powerful biological effects may also apply to GM 
plants containing similar constructs, particularly those containing lectins, such as soya beans or any plants expressing lectin genes or transgenes.

This study was supported by Scottish Office: Agriculture, Environment, and Fishery Department (grant number FF 818).

1 Gatehouse AMR, Down RE, Powell KS, et al. Transgenic potato plants with enhanced resistance to the peach-potato aphid Myzus persicae. Ent Exp Appl 1996; 79: 295-307.

2 Pusztai A, Ewen SWB, Grant G, et al. Relationship between survival and binding of plant lectins during small intestinal passage and their effectiveness as growth factors. Digestion 1990; 46 (suppl 2): 306-16.

3 Marsh NM, Ensari A. The gut associated lymphoid tissue and immune system. In: Whitehead R, ed. Gastrointestinal and oesophageal pathology. 2nd edn. Edinburgh: Churchill Livingstone, 1995: 201-25.

Department of Pathology, University of Aberdeen, Aberdeen AB25 2ZD, UK (S W B Ewen FRCPath, A Pusztai PhD)

Correspondence to: Dr Stanley W B Ewen (e-mail: $\underline{\text { s.w.b.ewen@abdn.ac.uk) }}$

Differential binding of the insecticidal lectin GNA to human blood cells

Lancet Volume 354, Number 918716 October 1999 
Brian Fenton, Kiri Stanley, Steven Fenton, Caroline Bolton-Smith

Evidence of snowdrop lectin binding to human white cells supports the need for greater understanding of the possible health consequences of incorporating plant lectins into the food chain.

See Commentaries by Horton and Kuipers et al

There is interest in the possible use of lectins to protect food plants from attack by insects. Many of these carbohydrate-binding proteins agglutinate vertebrate red blood cells. The lectin peanut agglutinin (PNA) also binds to the ThomsenFriedenreich antigen on the surfaces of some human colon cells. After eating peanuts, PNA has been detected in the blood after 1 hour1 and individuals who express this antigen have increased rates of colonic cell division, with possible health implications.2 PNA does not appear to be under consideration in an insecticidal role. Galanthus nivalis (snowdrop) agglutinin (GNA) is however under consideration and transgenic plants expressing GNA have been constructed.3 GNA recognises terminal 1-3-linked mannosyl residues. The distribution, abundance, and microheterogeneity of this structure on hu! man glycoproteins is largely unknown, particularly for membrane-bound receptor proteins. Although the conventional view is that mammalian intestinal cells possess no free mannose residues, and therefore cannot bind GNA, there have been reports of dietary effects of GNA in rats, including hypertrophy of the small intestine.4 GNA is highly resistant to digestion, and tests on human cells suggest that GNA can cause increase in mitosis. Although mitogenic stimulation requires both lectin binding and activation of appropriate cell-surface receptors, poorly mitogenic lectins can act in synergy with other compounds to increase mitotic indices. In addition, GNA could react with other receptors and block their normal function in at least some tissues and in at least some individuals. 
We examined proteins isolated from human buffy coats and red blood cells taken on three different occasions from six healthy individuals (aged more than 60 years) for their reactivity with GNA. Sodium dodecyl sulphate polyacrylamide gel electrophoresis and western blot procedures were used to transfer proteins onto a nitrocellulose support matrix.5 This procedure was followed by detection with commercially available biotinylated lectins and alkaline phosphatase linked to streptavidin. Our results show that human white blood cells have many proteins that strongly bind to GNA (figure). This binding was partially inhibited in the presence of mannose. Red blood cells showed little reactivity with GNA which was consistent with the lack of agglutinating activity of GNA for human erythrocytes and also indicated that blood group variation was not an issue.

Lane 1 molecular weight markers; lanes 2-7 individuals

1-6 buffy coats; lanes 8-13 RBCs; lane 14 ribonuclease A (not mannosylated; negative control); lane 15 ribonuclease B (mannosylated; positive control)

Equal volumes of buffy coat and RBC were used. Note the intense staining of glycoproteins in the buffy coat layer but weak staining of RBC glycoproteins. Arrows indicate possible polymorphic glycoproteins.

These data strongly suggest that human glycosylation pathways in white cells are capable of synthesising substantial quantities of terminal mannose moieties that interact with GNA. Furthermore the reaction appears to vary (indicated by arrows). This work highlights the need for a much greater understanding of the interactions between plant lectins and human glycoproteins before they can be safely incorporated into the food chain.

1 Wang Q, Lu-Gang Y, Campbell BJ, Milton JD, Rhodes JM. Identification of intact lectin in peripheral venous blood. Lancet 1998; 352; 1831-32. 
2 Ryder SD, Jacyna MR, Levi AJ, Rizzi PM, Rhodes JM. Peanut ingestion increases rectal proliferation in individuals. Gastroenterology 1998; 114: 44-49.

3 Down RE, Gatehouse AMR, Hamilton WDO, Gatehouse JA. Snowdrop lectin inhibits development and decreases fecundity of the glasshouse potato aphid (Aulacorthum solani) when administered in vitro and via transgenic plants both in laboratory and glasshouse trials. J Insect Physiol 1996; 42: 1035-45.

4 Pusztai A, Kininx, J Hendriks H, et al. Effect of the insecticidal Galanthus nivalis agglutinin on metabolism and the activities of brush border enzymes in the rat small intestine. J Nut Biochem 1996; 7: 677-82.

5 Fenton B. Clark JT, Wilson C, McBride J, Walliker D. Polymorphism of a 35-48kDa Plasodium falciparum merozoite surface antigen. Mol Biol Parasitol 1989; 34: 79-86.

Scottish Crop Research Institute, Invergowrie, Dundee, UK (B Fenton PhD, K Stanley BSc), and Nutrition Research Group, Cardiovascular Epidemiology Unit, University of Dundee, Ninewells Hospital and Medical School, Dundee DD1 9SY, UK (S Fenton MSc, C Bolton-Smith PhD)

Correspondence to: Dr Caroline Bolton-Smith 


\section{MEMORANDUM}

Six months ago Dr. Pusztai voiced his concern in a TV programme that present testing procedures to establish the safety of foodstuffs containing genetically modified (GM) material may not be adequate. Two days later he was suspended by the Rowett Research Institute, Aberdeen, for being responsible for the release of misleading information, gagged and threatened by legal action if he spoke out in his own defence. All his scientific data were confiscated and, to establish whether or not he had committed fraud, an Audit Committee was set up. Its remit was to investigate whether, as Dr. Pusztai claimed, the growth and immune responsiveness of rats fed diets containing GM potatoes was depressed. Regrettably, although a Report was written on the conclusion made by the Audit Committee, this has only been discussed by selected people in line with the Rowett's original intention that "these new findings will not be released by the Institute but will be scrutinized by collaborating groups of scientists and official expert committees". Unfortunately, neither the results of the GM research nor of the Audit have been fully revealed. Instead, several months later the Rowett published a summary of the conclusions of the Audit Report which stated unequivocally that Dr. Pusztai's conclusions were not justified by his experimental data.

Those of us who have known Dr. Pusztai's work or have collaborated with him, were shocked by the harshness of his treatment by the Rowett and even more by the impenetrable secrecy surrounding these events. It is an unacceptable code of practice by the Rowett and its Director, Professor James, to set themselves up as arbiters or judges of the validity of data which could have such a profound importance not only for scientists, but also for the public and its health. Fortunately, to comply with the Audit rules, the Rowett had to return Dr. Pusztai's data and give him the right to comment on the Audit Report. Although the results included in this report appeared to be arbitrarily selected and biased towards brushing aside the conclusions of his 
experimental findings, the data contained within the Audit Report itself nevertheless showed very clearly that the transgenic GNA-potato had significant effects on immune function and this alone is sufficient to vindicate entirely Dr. Pusztai's statements. Dr. Pusztai decided to make his response to the Director of the Rowett and SOAEFDS (Scottish Office, who funded the project) in the form of an Alternative Report. However, the existence of his Report has never been acknowledged. In the interest of transparency and to follow the tradition of scientific exchange of views and data between scientists, and to peer-review his findings before publication, a number of independent scientists approached Dr. Pusztai with the view to study his results in detail and have given us their written reviews.

The independent scientists who have reviewed Dr. Pusztai's data and case, and who agreed with the content of this Memorandum, are:

Prof. K. Baintner, Department of Physiology, Pannon Agricultural University, Kaposvar, Hungary

Prof. J. Cummins, Emeritus Prof. Genetics, Ontario, Canada

Dr. S.W.B. Ewen, Department of Pathology, Aberdeen Royal Hospitals, Aberdeen, Scotland, UK

Prof. R. Finn, Department of Medicine, The University of Liverpool, United Kingdom

Dr. M.F. Fuller, Stony Brook, New York, USA

Prof. B.C. Goodwin, Schumacher College, Dartington, Devon, United Kingdom 
Dr. J. Hoppichler, Federal Institute for Less-Favoured and Mountainous Areas, Vienna, Austria

Dr. C.V. Howard, Fetal and Infant Toxico-Pathology, The University of Liverpool, United Kingdom

Dr. J. Koninkx, Department of Pathology, Faculty of Veterinary Medicine, University of Utrecht, The Netherlands

Prof. A. Krogdahl, Norwegian School of Veterinary Science, Oslo, Norway

Dr. K. Lough, Bankhead, Aberdeen, Scotland (formerly of the Rowett Research Institute, Aberdeen, Scotland, UK)

PD. Dr. D. Mayer, Heidelberg, Germany

Prof. F.V. Nekrep, Biotechnical Faculty, Zootechnical Department, University of Ljubljana, Slovenija

Prof. S. Pierzynowski, Department of Animal Physiology, University of Lund, Sweden

Prof. S. Pongor, Protein Structure and Function Group, International Centre for Genetic Engineering and Biotechnology, Trieste, Italy

Prof. I. Pryme, Department of Biochemistry and Molecular Biology, University of Bergen, Norway 
Prof. J. Rhodes, Gastroenterology Research Group, The University of Liverpool, United Kingdom

Dr. L. Rubio, Department of Animal Nutrition, Estacion Experimental del Zaidin, Granada, Spain

Prof. M. Sajgo, Department of Chemistry and Biochemistry, Godollo University of Agriculture, Hungary

Prof. U. Schumacher, Department of Neuroanatomy, University of Hamburg, Germany

Dr. B. Tappeser, Institute for Applied Ecology, Freiburg, Germany

The reviews written by these scientists allowed us to compare the conclusions of both the Audit and the Alternative Reports and to establish the validity of Dr. Pusztai's claims. No data will be given here but, as in any referee's report, we give our summary assessment and conclude that the data would be acceptable for scientific papers. In light of the personal harm done to Dr. Pusztai we conclude also that it is imperative to make available the reviews as well as our conclusion to the public, either as publications in scientific journals or otherwise. There is no doubt in our minds that the reviews will remove the stigma of alleged fraud and will restore Dr. Pusztai's scientific credibility.

We are of the opinion that although some of the results are preliminary, they are sufficient to exonerate Dr. Pusztai by showing that the consumption of GNA-GMpotatoes by rats led to significant differences in organ weight and depression of lymphocyte responsiveness compared to controls. There was also strong evidence that GNA-GM tubers were not substantially equivalent to parent potatoes and 
indeed the two lines of GNA-GM-potatoes in the study were also different. This makes a very strong case for the necessity of performing further work to elucidate the toxico-pathological importance of these findings. Unfortunately, as publication of scientific papers is a long-drawn out process, and as there is an urgent need to bring these data into the public arena right now such that the safety and hazards presented by GM crops could be properly debated and assessed, we decided to publish this Memorandum.

Signed by:

Prof. E. Van Driessche

Laboratory of Protein Chemistry, Vrije Universiteit Brussel, Brussels, Belgium

and

Prof. T.C. Bøg-Hansen

The Protein Laboratory, University of Copenhagen, Denmark

\section{LLAMAMIENTO DE LOS CIENTÍFICOS: \\ POR UNA MORATORIA EN LOS CULTIVOS TRANSGÉNICOS Y LA PROHIBICIÓN DE LAS PATENTES SOBRE LA VIDA}

Nosotros, los científicos que firmamos abajo, instamos a nuestros gobiernos a que:

impongan de inmediato una moratoria de al menos cinco años de duración sobre las liberaciones al medio ambiente de cultivos, alimentos y piensos transgénicos.

Prohíban las patentes sobre organismos vivos, estirpes celulares y material genético. 
Apoyen una investigación pública independiente y exhaustiva sobre el futuro de la agricultura y la seguridad alimentaria para todos y todas, que tome en consideración todo el abanico de descubrimientos científicos, así como las implicaciones éticas y socioeconómicas.

1. Nos preocupa mucho la continuada liberación y comercialización de cultivos, alimentos y piensos transgénicos a la vista de las pruebas científicas cada vez más numerosas de los peligros que esto representa para la biodiversidad, la seguridad alimentaria y la salud animal y humana, mientras que ni la necesidad ni los beneficios de una agricultura basada en la ingeniería genética han sido probadas. Nuevos descubrimientos científicos nos han convencido de la necesidad de una moratoria inmediata sobre liberaciones al medio ambiente.

Los transgenes de resistencia a herbicidas se han propagado (por polinización cruzada) desde la colza y la remolacha a especies silvestres emparentadas, creando muchas especies de "malísimas hierbas" en potencia. Una investigación muestra que los transgenes pueden escapar de la planta con una probabilidad hasta treinta veces superior a los propios genes de ésta.

Las toxinas insecticidas del Bt (Bacillus thuringiensis), ya transferidas por ingeniería genética a un amplio abanico de plantas liberadas al medio ambiente, pueden acumularse en el suelo y tienen impactos devastadores sobre insectos polinizadores y otros tipos de insectos benéficos.

Recientes revelaciones sobre los experimentos con animales nutridos a base de alimentos transgénicos han arrojado serias dudas sobre la seguridad de tales alimentos. Ratas alimentadas con patatas transgénicas (a las que se había incorporado el gen de la lectina de la campanilla blanca) sufrieron una significativa 
reducción en el peso de muchos de sus órganos, debilitamiento de la respuesta inmunológica y señales de infección viral.

Investigación realizada en Holanda (con un intestino artificial) muestra que los genes de resistencia a los antibióticos empleados como marcadores en bacterias transgénicas pueden transferirse horizontalmente a bacterias del tracto digestivo humano con una sustancial frecuencia de 10-7

Investigadores estadounidenses documentaron una amplia transferencia horizontal de un parásito genético de cierta levadura al genoma mitocondrial de las plantas superiores, lo que suscita graves preocupaciones sobre la transferencia horizontal incontrolable de transgenes y genes marcadores desde las plantas transgénicas liberadas al medio ambiente.

2. Las patentes sobre organismos vivos, estirpes celulares y genes amparadas en los acuerdos TRIP (Trade Related Intellectual Property Rights) son actos de piratería que afectan a recursos intelectuales y genéticos de naciones del Tercer Mundo, y al mismo tiempo incrementan el oligopolio de unas pocas empresas multinacionales sobre la producción y distribución de alimentos. Se está marginando a los pequeños agricultores del mundo entero, lo que amenaza la seguridad alimentaria de todos en el largo plazo.

3. Los gobiernos de las naciones industrializadas, al votar a favor de las patentes sobre organismos vivos, estirpes celulares y genes -incluyendo genes humanos--, corren el riesgo de permitir a las multinacionales la explotación irrestricta de los ciudadanos y recursos naturales de sus propios países, a través de los acuerdos internacionales que se están negociando en la OMC y otros foros internacionales. La legislación ambiental, las normas sobre seguridad alimentaria e incluso los derechos 
humanos esenciales se sacrificarán a los imperativos de beneficio de las transnacionales.

4. En los comités de asesoramiento a los gobiernos no están representados suficientemente los científicos independientes sin vínculos con la industria. El resultado es que una tecnología inmadura, insuficientemente investigada, ha sido lanzada prematuramente a los mercados, minimizando o ignorando las pruebas científicas de los peligros (cuando no eliminando dicha información); se está realizando muy poca investigación independiente sobre los riesgos.

5. Estas tecnologías están impulsadas por una desfasada ciencia genética determinista que presupone que los organismos están determinados de forma sencilla por genes constantes e invariables susceptibles de ser manipulados arbitrariamente para ponerlos al servicio de nuestras necesidades; mientras que los descubrimientos científicos acumulados en los últimos veinte años han desmentido cualquier hipótesis de determinismo genético. La nueva genética favorece una perspectiva ecológica holista en todo lo que atañe a los genes. El genoma no es constante e invariable, sino fluido y dinámico en respuesta a la fisiología del organismo y al medio ambiente externo; y precisan una ecología en equilibrio para mantener su propia estabilidad.

\section{CIENTÍFICOS IMPULSORES DEL LLAMAMIENTO:}

Prof. Arpad Pusztai, inmunólogo, antes en el Rowett Institute, Reino Unido.

Dr. Susan Bardocz, genetista, Rowett Institute, Reino Unido.

Prof. Joe Cummins, genetista, University of Western Ontario, Canadá. 
Prof. Martha Crouch, bióloga, Indiana University, EE.UU.

Prof. Terje Traavik, virólogo, University of Tromso, Noruega.

Prof. Brian Goodwin, biólogo, Schumacher College, Reino Unido.

Prof. Martha R. Herbert, neuróloga pediátrica, Massachusetts Gen. Hospital, EE.UU.

Dr. Mae-Wan Ho, genetista y biofísica, Open University, Reino Unido.

Dr. Vyvyan Howard, patóloga-toxicóloga, Liverpool University, Reino Unido.

Dr. Vandana Shiva, Research Institute for Science and Ecology, India.

Prof. Peter Saunders, biomatemático, King's College, Londres, Reino Unido.

Dr. Christine von Weizsaeker, Ecoropa, Alemania.

Dr. Tewolde Egziabher, agrónomo, Environmental Protection Authority, Etiopía.

Prof. Phil Bereano, ingeniero, University of Washington, EE.UU.

Personas de contacto: Mae-Wan Ho/Angela Ryan, Institute of Science in Society, Reino Unido.

Tel/Fax: 44-181-441-6480.

Correo electrónico: i-sis@Dircon.co.uk 
Llamamiento difundido en Plant Breeding News 96 (boletín electrónico de la FAO), 27 de abril de 1999. Traducción de Jorge Riechmann (Fundación $1^{\circ}$ de Mayo, Madrid).

Fundación $1^{\circ}$ de Mayo

C/Arenal 11, 1', 28013 Madrid

Tels. 913640601, 913640838; Fax 913641350

\section{UK SCIENTISTS MEETING WITH MINISTER}

\section{NORFOLK GENETIC INFORMATION NETWORK (ngin)}

http://members.tripod.com/ ngin/

The second issue of GM-FREE magazine is out (you can subscribe from their website: http://wkweb4.cableinet.co.uk/pbrown/index.htm or mailto:gmfree@cableinet.co.uk).

Congratulations to GM-FREE - this issue is as outstanding as the first.

Among many interesting items, it contains a record by scientist Angela Ryan of part of a meeting on GMOs in the office of UK Environment Minister, Michael Meacher.

Among the various scientists present were Dr Mae-wan Ho, Dr Michael Antoniou and Dr Phil Dale of the John Innes Centre in Norwich.

Here is Angela Ryan's complete record of the meeting.

Michael Meacher Meets Scientists 
Report on a Meeting of Molecular Biologists called by Michael Meacher on March 31st 1999

Prepared by Angela Ryan

In attendance:

The Right Honorable Michael Meacher, Minister for the Environment

Paul Burrows, Chemicals and Biotechnology division, DETR

Steven Tindale, Sustainable Development, DETR

Adrian Butt, Intern, DETR

Scientists

Professor Don Grierson, Plant Molecular Geneticist, Nottingham University

Dr Mae-wan Ho, Geneticist and Biophysicist, Open University

Angela Ryan, Molecular Biologist and assistant to Dr Mae-wan Ho, Open University

Dr Michael Antoniou, Gene Therapist, Guys Hospital, London

Dr Mark Bailey, NERC Molecular Ecology Lab, IVEM Oxford

Dr Andrew Lilley, NERC Molecular Ecology Lab, IVEM Oxford

Dr Ian Garner, PPL Therapuetics, Roslin Institute, Scotland. Member of ACRE

Dr Phil Dale, John Innes Center, Norwich. Member of ACRE

A group of scientists (see above) were invited to the DETR by the Right Honorable Michael Meacher. The agenda was set to discuss the special safety concerns raised by the effects of random insertion of DNA vectors and horizontal gene transfer. 
Following formal introductions the minister asked the scientists: does GM raise issues beyond conventional breeding practices?

Dr Phil Dale responded first and spoke of how GM was no different from conventional breeding practices except that it is more precise. In conventional breeding, seeds are irradiated to cause mutations at points all along the germ line DNA. Following germination the seedlings undergo analysis and selection protocols which eventually lead to the isolation of varieties that can be used in farming. With GM a specific gene can be inserted in a single copy so that a specific desired trait can be introduced into an organism. The site of insertion is determined using southern blotting and the chromosomal location is also determined using fluorescent in situ hybridization (FISH). The expression pattern of the insert is analysed over many generations to demonstrate that it is completely stable and has become a constitutive part of that organism. GM is much more precise and therefore safer than conventional breeding.

Dr. Mae-Wan Ho disagreed. GM technology is not at all precise. She identified four special safety concerns arising from current transgenic technologies.

1. The exotic genes and gene products introduced into the transgenic organisms may be toxic. Antibiotic resistance marker genes are also often left in the transgenic organisms.

2. Unintended, unexpected effects of random gene insertion and interaction between foreign genes and host genes in the transgenic organisms which could generate toxins and allergens.

3. The gene-constructs inserted into the transgenic organisms are also novel. Foreign genes are typically introduced as 'gene expression cassettes' each with a strong viral 
promoter/enhancer to boost expression to very high levels. The trangenic organism is, in effect, under permanent metabolic stress. The promoter most frequently used is from the cauliflower mosaic virus (CaMV), which is closely related to human hepatitis B virus, and less closely, to retroviruses such as the AIDS virus. The CaMV promoter can drive the synthesis of related viruses. It is active in all living systems from bacteria to higher plants. Two kinds of potential hazards exist: the reactivation of dormant viruses, and recombination between the CaMV promoter and other viruses, dormant or otherwise, to generate new, super-infectious viruses or viruses with broadened host-range.

4. The spread of transgenes and antibiotic resistance marker genes, not only by ordinary cross-pollination, but especially by secondary, horizontal gene transfer to unrelated species. The same mechanisms that enable genes to insert into the genome can help them jump out again. Integrases, enzymes catalyzing the integration, which exist in all organisms from viruses to higher plants and animals, also act as disintegrases, catalyzing the reverse reaction. There is already evidence suggesting that the foreign genes inserted by vector in a transgenic plant may be up to 30 times more likely to escape than the same gene created by mutagenesis. Horizontal gene transfer is well-documented in a special report commissioned by the Norwegian Government Directorate of Nature Management from independent virologist and genetic engineer, Terje Traavik, and recently published in English. Trangenic plants of the current generation are unpredictable, unstable, do not breed true and do not perform consistently in the field. Molecular analysis must be done to characterize the insert (s) and demonstrate stability of the insert(s) at least over five successive generations. Such data is often missing from applications for approval for field trials or marketing.

Dr Michael Antonio explained the way in which genes work in genomes. Genes do not function in isolation, they work in groups and are highly integrated with one 
another. They are constantly interacting and are under strict molecular control where genomic position is important. There are regions of active transcription where genes are being transcribed and there are silent regions where no transcription is taking place. A gene vector can land in either region but in order for it to be actively transcribed it must land in a region of active transcription. Random insertion can cause insertion mutagenesis and it is well understood that many viral induced cancers are caused in this way. Insertion may also disrupt the gene regulation and natural groupings of the genes that are functional in the region of insertion. The use of strong promoters and enhancers in the vectors may cause metabolic stress to the transformants. Both these factors may lead to the emergence of novel toxins or allergens and there is no way to predict this at present for we are in the early days of understanding gene function. In convention breeding, the natural order or groupings of the genes is not disturbed. Point mutations may result in changes to the amino acid sequence of the gene products but that does not interfere with the natural groupings of the genes and alleles, which we know to be vital to gene regulation. There are just too many unknowns at present.

The Right Honorable Michael Meacher then made the point that novel toxins and allergens may occur in organisms being produced via conventional breeding as well and perhaps further scientific study should have been done on organisms being produced in this way?

Dr Michael Antonio and Dr Mae-wan Ho both agreed that this is a very valid point.

Dr Phil Dale reasserted his view that although the GM constructs are inserted randomly at first, further analysis via southern blotting and FISH isolates the precise region in the genome and on which chromosome the insert has integrated. 
Dr Michael Antonio replied and said that without further gene mapping work it is impossible to understand how the act of insertion is affecting the recipient genomes gene expression. The full extent of gene regulation is yet to be elucidated and the effects of insertion on the recipient genome will be largely unknown until we have gained a better understanding of gene function. Knowing where an insert is on a southern blot and which chromosome it is on, does not constitute knowing where it is in the recipient genome's gene regulation system. He then strongly recommends further research in gene mapping in order to understand this important safety aspect of GM.

Dr Ian Garner stated that it has been known for many years, from the work of Barbara Maclintock, that genomes are fluid and dynamic. GM is doing nothing more beyond what nature has been doing for millions of years.

Dr Andrew Lilly added that the rate of evolution in bacteria is incredibly rapid and that they are constantly changing their gene expression. His colleague, Dr Mark Bailey reasserted that GM is merely utilising an already well established natural system.

Dr Mae-wan Ho agreed that bacteria evolved rapidly and drew attention to a paper by J. de Vries \& W. Wackernagel, Mol. Gen.. Genet.. (1998) 257: 606-613 regarding transfer frequency from transgenic plant DNA to soil bacteria. She pointed out that in transgenic potatoes, as little as $18 \mathrm{ng}$ of potato DNA $(2.5 \times 103$ genome equivalents, each with one copy of an the Kanamycin-resistant gene npt11) was required to produce one kanamycin-resistant bacterial transformant. She added that GM may greatly accelerate the rate of horizontal gene transfer and enlarge it's scope.

Dr Mark Bailey said he knew about this paper because he reviewed it and he knows the authors personally. He warns we must be careful about misinterpreting this 
paper. These experiments were conducted under strict laboratory conditions and the plasmids were designed to have homology with the Kanamycin-resistant gene within the transgenic plant DNA. This would not occur normally in the wild in the absence of such specific homology.

Angela Ryan questioned this remark and stated that many gene constructs used in GM do contain, to a greater or lesser degree, plasmid DNA, viral DNA especially viral promoters e.g. CaMV promoter, long terminal repeats (LTRs) and left and right borders, all of which are highly conserved and may in theory find sequence homology in the wider environment.

Dr. Phil Dale remarked that just because it happens in the laboratory does not mean it happens in nature.

Dr Mae-Wan Ho asked whether he could guarantee it will never take place in nature, and added that although these experiments were conducted in the laboratory the system used was actually adapted to natural transformation and therefore could take place in the wild. Furthermore, homology is not neccessary for successful horizontal gene transfer. Many insertions into the genome happen without sequence homology, especially those involved in making transgenic organisms.

The Right Honorable Michael Meacher then asked just how much evidence will be needed before we can be sure that GMOs are safe? And how long will it be until such time, five or maybe ten years?

Dr Mae-wan Ho responded and confirmed that there are many unanswered questions surrounding GMOs and that is imperative that the precautionary principle be applied. An inverse precautionary principle has been at work regarding GMOs to date. She recommended an immediate ban on all commercial plantings of GMO 
crops and called for a five year moratorium in order to further identify the risks and conduct the necessary experimental research. A full independent inquiry into the future of agriculture and food security for all was also needed.

Dr Ian Garner and Dr Phil Dale said they did not believe a moratorium was necessary.

Steven Tindale then asks about the CaMV promoter and its affects?

Dr Phil Dale said that we eat the CaMV all the time and it is present in many of the vegetables that make up our staple diet. It does not have any harmful effects.

Dr Mae-wan Ho refuted this remark and said that there is a great difference between the CaMV we may eat everyday in vegetables and the CaMV promoter used in GMOs. Viruses are protected in the environment by a protein coat which also confers species specificity. The CaMV cannot enter mammalian cells because it's protein coat is specific to plant cells. The CaMV promoter used in GMOs however, comes in the form of naked viral DNA and naked DNA of any sort is highly infectious. The CaMV promoter is also highly conserved and has been shown to have sequence homology with other viruses. It is closely related to human Hepatitis B virus and also to retroviruses like HIV. It is a very strong promoter, it shouts in a recipient genome to be transcribed and that is why it is so widely used. It may recombine with latent or infecting viruses within the host or beyond and give rise to new super-viruses. The wide use of the CaMV promoter alone carries enough risk to impose an immediate moratorium on GMOs.

The Right Honorable Michael Meacher then asked the scientists for their views on Dr Pusztai's results. 
Dr Ian Garner stated that we must be very careful not to take too seriously experimental data that has not been peer reviewed.

Dr Mae-wan Ho refuted this remark and explained that Pusztai's work has been peer reviewed by 20 scientists who confirmed his results as significant.

Dr Phil Dale added that lectins are well-known toxins and therefore the result is not unusual considering this.

Dr Michael Antonio clarified this comment and said that the snowdrop lectin had been specifically selected because it had no toxicity in mammalian cells, it was only toxic to insects. He explained that the transgenic potato contained the snowdrop lectin to confer insect resistance.

Angela Ryan then added that Dr Pusztai's experiments were designed to develop new methods of testing GM food. He had worked for seven years on this and was alarmed by the results he found. The symptoms observed in the rats were consistent with viral infection.

Dr Phil Dale and Dr Ian Garner said they did not believe this.

Dr Mae-wan Ho confirmed that the rats had reduced weight in vital organs, impairment of immunological responsiveness and signs suggestive of viral infection.

Steven Tindale then asked if other feeding experiments have been conducted?

Dr Phil Dale explained that because GM food is completely digested in the gut, feeding experiments had been considered unnecessary, although he wasn't sure what 
had happened in America. Nobody had died yet from eating GM food and he believes it to be perfectly safe.

Dr Mae-wan Ho confirmed that Dr Pusztai's experiments were the first comprehensive feeding experiments to be conducted. She refuted the claim that GM food is completely digested in the gut and referred to evidence which demonstrates that viral and plasmid DNA fed to mice had been found to resist digestion in the gut. Large fragments passed into the bloodstream and entered white blood cells, spleen and liver cells. It was found attached to mouse DNA, suggesting integration, and when fed to pregnant mice it was found in the nucleus of cells of the foetus and newborn. She warned that if GM foods were having ill-effects on the public we would not know about them as no one is monitoring for such effects. She pointed to the catastrophic thalidomide incident in which 8000 babies with truncated limbs were born before thalidomide was admitted as the harmful agent. Dr Pusztai's work should be repeated and not be dismissed in anyway.

The Right Honorable Michael Meacher confirmed that the Government was taking Dr Pusztai's experiments very seriously and would certainly not dismiss them.

At this point the meeting came to and end and Michael Meacher thanked all the scientists for coming along and giving their time. He said he has come to a better understanding of the complications regarding GMOs now, and that he would welcome further help and advise.

Dear GENET-forum readers,

attached you will find the web page

http://www.bma.org.uk/public/science/genmod.htm 
containing the report "The Impact of Genetic Modification on Agriculture, Food and Health - An Interim Statement" of the British Medical Association (Board of Science and Education) from May 1999.

Yours,

Hartmut Meyer 